\title{
THE ROLE OF REMORSE IN SENTENCING
}

\section{$1 \quad$ Introduction}

It has become an established feature of the South African sentencing practice to consider the level of remorse displayed by the accused ( $S \vee M$ (Centre for Child Law as Amicus Curiae) 2007 (2) SACR 539 (CC) par [115]). Genuine contrition or remorse is generally regarded as a mitigating factor whilst the absence thereof is considered to be an aggravating factor. Our courts link the presence of remorse with the prospect of the rehabilitation of the offender (Terblanche "Sentencing" 2010 Annual Survey of South African Law 1279 1287-1288; S v Ntuli 1978 (1) SA 523 (A) 528B-C; S v PN 2010 (2) SACR 187 (ECG); S v De Klerk 2010 (2) SACR 40 (KZP) par [28]; S v Langa 2010 (2) SACR 289 (KZP) par [36]; S v Onose 2012 JDR 1074 (ECG) par [9]; and $S$ v Keyser 2012 (2) SACR 437 (SCA) par [29]). In S v Seegers (1970 (2) SA 506 (A) $512 \mathrm{G}-\mathrm{H}$ ) Rumpff JA held that remorse, as an indication that the offence will not be committed again, is an important consideration, in suitable cases, when the deterrent effect of a sentence on the accused is considered. This note considers the meaning of "remorse" in the eyes of our courts, the approach of South African courts (in particular the Supreme Court of Appeal) to the role of remorse in sentencing, as well as the question whether the presence or absence of remorse can truly be determined by a court.

\section{The meaning of remorse}

A variety of definitions of remorse exists in literature (Proeve, Smith and Niblo "Mitigation without Definition: Remorse in the Criminal Justice System" 1999 32(1) Australian and New Zealand Journal of Criminology 16 17; and Brooks and Reddon "The Two Dimensional Nature of Remorse: An Empirical Inquiry into Internal and External Aspects" 2003 Journal of Offender Rehabilitation 2$3)$. In fact there is a need for a proper delineation of an adequate concept of remorse (Proeve et al 1999 32(1) Australian and New Zealand Journal of Criminology 24). Turning to our courts' views on remorse, it was held in $S v$ Martin (1996 (2) SACR 378 (W) 383G-I) that remorse "denotes repentance, an inner sorrow inspired by another's plight or a feeling of guilt". More recently the SCA described remorse as "a gnawing pain of conscience for the plight of another". The court held that genuine contrition could only come from an appreciation and acknowledgement of the extent of one's error. Mere regret by the offender for his or her conduct or for the adverse consequences of the criminal conduct is not regarded as remorse ( $S$ v Matyityi 2011 (1) SACR 40 (SCA) par [13]). There must be some factual basis for a court to make a finding of remorse. In $S \vee$ Matyityi it was held that the court had to look at the "surrounding actions of the accused, rather than what he says in court". In $S v$ 
Thole (2012 (2) SACR 306 (FB) par [13]) it was held that "contrition cannot be construed, it must be demonstrated".

\section{$3 \quad$ Taking the court into one's confidence}

One recurring theme in case law is that the accused must take the court fully into his confidence in order for the court to assess the sincerity of his penitence and remorse ( $S$ v Seegers supra 512G-H; and S v Morris 1972 (2) SA 617 (A)). Failure to do so is seriously frowned upon. Taking the court into one's confidence apparently means that the accused must take the witness stand so that the sentencing court can have a proper understanding of what motivated the accused to commit the crime; what has since provoked his change of heart and whether he does indeed have a true appreciation of the consequences of his actions ( $S$ v Matyityi supra par [13]; $S$ v Kgantsi 2012 JDR 0856 (SCA) par [11]; $S$ v Keyser supra; and $S$ v Thole supra par [13]). According to the SCA, until and unless that happens, the genuineness of the contrition alleged to exist cannot be determined ( $S$ v Matyityi supra par [13]).

In $S$ v Martin (supra 383G-I) the court held that there was often no factual basis for a finding of true remorse if the accused "does not step out to say what is going on in his inner self". In that case the accused did not testify personally in mitigation of sentence; the court held that the "intensity, longevity and foundation" of the remorse could only be offered for full investigation and consideration by the accused himself. In $S$ v Morris (supra), the court held that it was the plain duty of the appellant to satisfy the court of his remorse by giving evidence himself, which could be tested by crossexamination. The appellant had pleaded guilty to and had been convicted on three counts of purchasing rough and uncut diamonds. The court of appeal was clearly not impressed by the appellant's failure to provide sufficient information as to the circumstances which led to his commission of the crime when stating the facts upon which his guilty plea was based. The court found that he had failed to dispel, with credible evidence, the inference that he volunteered information about the crime only as a result of pressure brought to bear upon him by the police.

Notwithstanding this, our courts have from time to time also credited offenders for mere expressions of remorse ( $S \vee$ Genever 2008 (2) 117 (C) par [10]; S v Scott-Crossley 2008 (1) 223 (SCA) par [35]; and S v Chipape 2010 (1) SACR 245 (GNP) par [17]).

\section{$4 \quad$ Pleading guilty and confessing}

A plea of guilty may be indicative of remorse but it becomes a neutral factor in a matter where the accused faces an open-and-shut case against him. Furthermore, a guilty plea without the accused "taking the court into his confidence", as explained above, also appears to be of little mitigating value ( $S$ v Van der Westhuizen 1995 (1) SACR 601 (SCA) 605D; S v Dembe 2010 (1) SACR (NK) par [15.4]; and S v Furlong 2011 JDR 0591 (SCA) par [16]). 
In $S$ v Mashinini (2012 (1) SACR 604 (SCA) par [24]) it was argued on behalf of the appellants, who had pleaded guilty to a charge of rape, that their plea of guilty had to be regarded as a sign of remorse for their deeds. The court rejected the argument and held that the appellants did not verbalize any remorse. The court held that it was clear that there was overwhelming evidence against the appellants and that they had no choice, but to plead guilty. The "overwhelming" evidence referred to by the court was that the complainant knew one of the appellants, rendering the issue of identification of him as one of the rapists not in dispute whilst the other appellant was linked to the commission of the offence by DNA evidence. The court found that "their plea under such circumstances can never be interpreted as remorse" (par [24]; and see also $S v$ Thole supra par [13]).

In $S$ v Britz ([2010] JOL 25567 (SCA)) the appellant was convicted on a number of charges of fraud after pleading guilty thereto. The Supreme Court of Appeal also held in this case that the fact that the appellant had pleaded guilty was not necessarily an indication of remorse. The court held that since there was a paper trail pointing to the fraud she "would have little option but to plead guilty". The appellant confessed to her employer 14 days after her resignation but the court accepted the uncontested evidence that she confessed because her fraudulent scheme was due to be uncovered in any event (par [11]). In $S$ v Michele (2010 (1) SACR 131 (SCA) par [7]) the court also found that a plea of guilty does not necessarily indicate true remorse, particularly where the crime (fraud), once discovered, would have been almost impossible to deny. In such circumstances a guilty plea was once more regarded as a neutral factor.

In $S \vee$ Kgantsi (supra par [11]) the court found "a distinct absence of remorse on the appellant's part, notwithstanding his plea of guilty on some of the offences". The court found that his lack of contrition was manifested by an untruthful plea explanation and testimony in respect of the murder which were directly at odds with his earlier confession before a magistrate. The court held that the appellant should be afforded the benefit of remorse as mitigating factor only to a very limited extent on the charge to which he had pleaded guilty.

An apology may also be indicative of remorse ( $S$ v Wilson 1986 (4) SA 477 (A) 481I; S v Sheppard 2003 JDR 0469 (W) 10; and S v Van der Merwe 2011 (2) SACR 509 (FB) par [64]). Accusing a truthful victim of being a liar may be indicative of an absence of remorse ( $S \vee C 1996$ (2) SACR 181 (C) 186B-C). A persistent refusal to accept responsibility and presenting false evidence are often found to be indicative of a lack of remorse $(S \vee$ Zulu 2012 JDR 0733 (KZP)). In S v Pakane (2008 (1) SACR 518 (SCA) par [43]) it was held that the accused's lack of remorse was:

\footnotetext{
"amply demonstrated by his iron resolve to conceal the truth to the bitter end from the elaborate steps he took to cover up and hamper police investigations; the shooting of the deceased in the head of which, if not perpetrated by him, he was nonetheless aware and should have prevented, especially as the leader of the mission; knowingly and silently watching innocent people languish in jail for
} 
two years for a crime he committed; the false statements made to the magistrate and police disciplinary tribunal; and giving false testimony in court".

In $S v$ Keyser (supra par [29]) the accused testified in mitigation. The SCA, however, found he had shown neither contrition nor remorse by testifying that he was not a criminal in any way. The court held that his insight was clearly limited and that it "does not bode well for his prospects of rehabilitation".

The Supreme Court of Namibia has held that for a confession or a plea of guilty to point to an inference of remorse, some evidence or, at the very least, some formal acknowledgement by the prosecution, had to be tendered to show that the accused was not compelled to plead guilty on the basis of the weight of the evidence against him. A finding of "some contrition" simply on account of an accused's plea of guilty or confession could not be justified (Harry de Klerk $v$ S case no SA 18/2003 par [16]).

In contrast the abovementioned decisions the Eastern Cape High Court recently held in $S v$ Onose (supra par [9]) that, although the appellant was convicted following a change of his plea from "not guilty" to "guilty" during the trial as a result of the production of fingerprint evidence which had linked him to the commission of the offences, the change in plea nevertheless signified an acceptance of responsibility and therefore a measure of remorse. The court held that an expression of remorse, however induced, was an indicator of a prospect of rehabilitation and, accordingly, had to be a factor to be weighed in favour of the accused.

\section{Conduct of the accused}

The facts in $S v$ Coales (1995 (1) SACR $33($ A)) were that the appellant and his wife had broken into premises with the intent to steal. While they were still inside the building they were overcome by remorse. They left the premises without taking anything and voluntarily handed themselves over to the police. Thereupon they confessed to every crime they had committed. They assisted the police in their further investigations and pleaded guilty at the trial. On appeal the court held that by doing so the appellant clearly demonstrated that he was truly remorseful and that his contrition and remorse were materially mitigating factors to which more weight should have been given by the trial court. It was also found that the fact that the appellant had a change of heart and was truly remorseful made him a better candidate for rehabilitation.

In $S \vee$ De Sousa (2008 JDR 1141 (SCA) par [7]) the appellant was convicted, pursuant to her plea of guilty on thirteen counts of fraud. The SCA held that the appellant had shown genuine remorse and contrition in (i) cooperating with the investigating officer from the time of her arrest; (ii) admitting her role in the commission of the offences; (iii) deposing to a witness statement and agreeing to testify against the co-perpetrator of the fraud; (iv) signing an acknowledgement of indebtedness in favour of the complainant in the sum of the extent of her benefit from the fraudulent scheme and thereafter paying that debt in full and (v) pleading guilty to the charges. 
An offer of compensation to the victim may be indicative of remorse ( $S \mathrm{~V}$ Masilela 2000 (1) SACR 571 (W) 573B; and S v Mushishi 2010 NR 559 (HC) par [8]). It seems, however, that belated undertakings to compensate the victim, without any serious attempt to do so, are of little mitigating value. In $S$ $\checkmark$ Michele (supra par [7]), for instance, it was argued on behalf of the appellants that they had shown remorse by pleading guilty and showing their willingness to repay the insurance company they had defrauded. The SCA, however, held that the clearest evidence of their remorse would have been their immediate repayment of the embezzled money.

In S v Rakgwhala (2012 JDR 1355 (GNP) par [50]) Kgomo J, interestingly, remarked that "restorative justice and/or the verbalisation of remorse and contrition are usually done by or through relatives, not by the perpetrator". Unfortunately the court did not elaborate on this aspect but it likely refers to traditional indigenous South African values. Kgomo $\mathrm{J}$ held that, since the accused (who had inter alia been convicted of murder following a guilty plea) did not tell his relatives what he did even after he was discovered, and since he did not send them to go and apologize on his behalf to the deceased's family his belated verbalization of contrition was not genuine or well meant. In a publication issued by the Department of Justice and Constitutional Development it is stated that restorative justice processes should "create the space for remorse, the expression of shame, apology, forgiveness, mercy and compassion, but should not force these responses to occur" (Department of Justice and Constitutional Development 2011 "Restorative Justice and the Road to Healing" http://www.justice.gov.za/rj/2011rj-booklet-a5-eng.pdf).

Co-operation with law-enforcement and prosecuting authorities in relation to the crime committed and assisting the police in the detection, investigation and prosecution of others have also been regarded as indications of remorse (Harry de Klerk v S supra). In S v Dippenaar (2006 JDR 0966 (SCA) par [11]) it was held that the magistrate sentencing the accused had misdirected himself in expressing doubt regarding the offender's remorsefulness. The SCA found that there was in fact ample and uncontradicted evidence at the magistrate's disposal showing that the appellant was remorseful. The court pointed out that it was due to the appellant's disclosures and co-operation with the police that the other offences he had committed came to light. He had also made a confession and pleaded guilty. The court held that it was the "clearest demonstration of remorse by an accused person and deserved to have weighed heavily with the magistrate".

In his minority judgment in $S \vee M$ (Centre for Child Law as Amicus Curiae) (supra par [115]) Madala $\mathrm{J}$ held that the appellant did not display any sign of remorse. This was evident in that she had committed further offences whilst on bail with the full knowledge of the impact that such action would have had on her children. She even continued to plan further acts of fraud whilst in prison. Madala $\mathrm{J}$ held that her lack of remorse arose from her recidivism. 


\section{Discussion}

Any endeavour to detect the presence or absence of remorse in surrounding factual circumstances or the genuineness of remorse is fraught with problems. Remorse is a complex notion (Murphy "Remorse, Apology and Mercy" 20074 Ohio St J Crim L 423 430-431; Brooks and Reddon 2003 Journal of Offender Rehabilitation 1-12) and is by its very definition subjective (O'Hear "Remorse, Cooperation and 'Acceptance of Responsibility': The Structure, Implementation and Reform of Section 3E1.1 of the Federal Sentencing Guidelines" 1997 Northwestern University LR 1556; and Ward "Sentencing Without Remorse" 2006 Loyola University Chicago LJ 134-138). Ward points out that "the failure of remorse is simply the failure of men to read the innermost thoughts and feelings of other men" and that no one really knows what remorse entails (Ward 2006 Loyola University Chicago LJ 167). In the absence of any empirical studies it is also questionable to link what is perceived to be remorse to the probability of rehabilitation. There is no evidence of any association between remorse and decreased recidivism (Proeve et al 1999 32(1) Australian and New Zealand Journal of Criminology 24). The cunning accused may "make all the right noises" by pleading guilty, apologizing, and compensating the victim in an attempt to get a lenient sentence without possessing any remorse whatsoever. Courts can therefore be deceived by faked displays of repentance and remorse (Ward 2006 Loyola University Chicago LJ 135; and Murphy "Well Excuse Me! - Remorse, Apology, and Criminal Sentencing" 2006 38(2) Arizona State LJ 379). On the other hand, psychological, developmental and cultural factors may inhibit remorseful offenders to express their remorse convincingly or to express it at all (Ward 2006 Loyola University Chicago LJ 135).

A plea of guilty ought to serve as a mitigating factor without any further requirements. A plea of guilty contributes to the effective administration of justice. In England and Wales, for instance, courts are required to give consideration to the reduction of the sentence for a guilty plea. A reduction in sentence is regarded as appropriate for the following reasons: a guilty plea avoids the need for a trial (thus enabling other cases to be disposed of more expeditiously), shortens the gap between charge and sentence, saves considerable cost, and saves victims and witnesses from the concern of having to give evidence (Sentencing Guidelines Council Reduction in Sentence for a Plea of Guilty Definitive Guideline http://sentencingcouncil .judiciary.gov.uk/docs/Reduction_in_Sentence_for_a_Guilty_Plea_-Revised_ 2007.pdf (accessed 2012-01-22). Also see $S$ v Aibeb (2011 JDR 1575 (Nm)). A guilty plea is therefore beneficial to the community (O'Hear 1997 Northwestern University LR 1514). Furthermore, by pleading guilty the accused accepts responsibility for his or her unlawful conduct. It would be unfair towards an accused not to regard a guilty plea in the face of an overwhelming case as a mitigating factor because the accused was left with no other choice but to plead guilty. The reality is that in South Africa many accused persons choose to plead not guilty, notwithstanding overwhelming evidence against them. Where they plead not guilty they either keep silent in 
the hope that the prosecution will fail to prove its case, or they tell lies that are rejected by the court ( $S \vee$ Mbatha 2009 (2) 623 (KZP) par [30]). The accused who pleads guilty makes the choice to do so. Furthermore, courts will mostly have to speculate as to the possible strength of the case against the accused upon a plea of guilty since detailed information is seldom placed before the court on this aspect after the accused has pleaded guilty. Experience has furthermore taught that evidence that may be perceived as overwhelming from the information contained in a police docket may unravel at the trial. Equally, an apparently flimsy case may turn out to be overwhelming during the trial.

$S \vee$ Mbatha (supra par [31]) Wallis $\mathrm{J}$ also pointed to a constitutional problem with our courts' approach to remorse. He held that there seem to be substantial dangers in inferring an absence of remorse from the exercise of a constitutional right, and treating that as an aggravating factor. The Constitution protects the right of an accused person to advance his or her defence. Webster $\mathrm{J}$ held that to infer from the fact that the accused has advanced a defence found to be dishonest, reflects a lack of remorse and therefore justifies the imposition of a more substantial sentence, "comes perilously close to holding that the accused is being sentenced not only for the crime that he has committed, but also for his failure to confess that crime". Wallis $\mathrm{J}$ held:

"All this seems to me inconsistent with the constitutional protection afforded to
the accused person to remain silent or put forward a defence to a charge. No
doubt it is for that reason that remorse usually comes into the scale in
mitigation of sentence, rather than in aggravation of it, and where its absence is
treated as aggravating, that is inferred from factors other than the accused's
conduct of his or her defence. In the present case I do not think that the fact
that the accused put forward a false defence is a seriously aggravating feature."

\section{$7 \quad$ Conclusion}

As our courts do not pass sentence in a mechanical fashion and give measurable discounts for mitigating factors it is nearly impossible to determine what effect displays of remorse have on the sentence eventually imposed. Pleading guilty, co-operation with the authorities and paying compensation to the victim are factors which in their own right ought to be regarded as mitigating. They all contribute to speedy and effective administration of justice and serve the interests of the victim and the community. The established practice to consider remorse in the sentencing as an indicator of prospects of rehabilitation seems to rest on dubious assumptions. We simply know too little about the concept of remorse to be able to use it as an indicator of anything. Herein lies the challenge: a proper empirical study of patterns of re-offending by those who had displayed remorse (as our courts see it) may shed important light on the issue.

Pieter du Toit North-West University, Potchefstroom Campus 